\title{
Technical Note: Silica stable isotopes and silicification in a carnivorous sponge Asbestopluma sp.
}

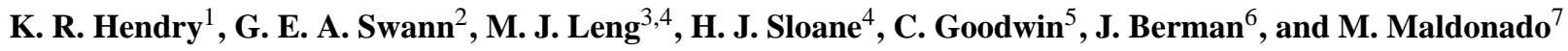 \\ ${ }^{1}$ School of Earth Sciences, University of Bristol, Wills Memorial Building, Queen's Road, Bristol, BS8 1RJ, UK \\ ${ }^{2}$ School of Geography, University of Nottingham, University Park, Nottingham, NG7 2RD, UK \\ ${ }^{3}$ Centre for Environmental Geochemistry, University of Nottingham, University Park, Nottingham, NG7 2RD, UK \\ ${ }^{4}$ NERC Isotope Geosciences Facilities, British Geological Survey, Keyworth, Nottingham, NG12 5GG, UK \\ ${ }^{5}$ National Museums Northern Ireland, 153 Bangor Road, Cultra, Holywood, Co. Down, Northern Ireland, BT18 0EU, UK \\ ${ }^{6}$ Ulster Wildlife, 3 New Line, Crossgar, Co. Down, Northern Ireland, BT30 9EP, UK \\ ${ }^{7}$ Centro de Estudios Avanzados de Blanes (CEAB-CSIC), Accés a la Cala St. Francesc, 14, Blanes 17300, Girona, Spain
}

Correspondence to: K. R. Hendry (k.hendry@bristol.ac.uk)

Received: 30 October 2014 - Published in Biogeosciences Discuss.: 2 December 2014

Revised: 29 April 2015 - Accepted: 13 May 2015 - Published: 5 June 2015

\begin{abstract}
The stable isotope composition of benthic sponge spicule silica is a potential source of palaeoceanographic information about past deep seawater chemistry. The silicon isotope composition of spicules has been shown to relate to the silicic acid concentration of ambient water, although existing calibrations do exhibit a degree of scatter in the relationship. Less is known about how the oxygen isotope composition of sponge spicule silica relates to environmental conditions during growth. Here, we investigate the vital effects on silica, silicon and oxygen isotope composition in a carnivorous sponge, Asbestopluma sp., from the Southern Ocean. We find significant variations in silicon and oxygen isotopic composition within the specimen that are related to unusual spicule silicification. The largest variation in both isotope systems was associated with the differential distribution of an unconventional, hypersilicified spicule type (desma) along the sponge body. The absence an internal canal in the desmas suggests an unconventional silicification pattern leading to an unusually heavy isotope signature. Additional internal variability derives from a systematic offset between the peripheral skeleton of the body having systematically a higher isotopic composition than the internal skeleton. A simplified silicon isotope fractionation model, in which desmas were excluded, suggests that the lack of a system for seawater pumping in carnivorous sponges favours a low replenishment of dissolved silicon within the internal tissues, causing kinetic fractionation during silicification that
\end{abstract}

impacts the isotope signature of the internal skeleton. Analysis of multiple spicules should be carried out to "average out" any artefacts in order to produce more robust downcore measurements.

\section{Introduction}

The formation of amorphous biogenic silica (or opal) by photosynthetic diatoms, which play a major role in the export of organic matter to the seafloor, is a key part to both the cycling of silicon and carbon in the Earth's climate system (Tréguer and De la Rocha, 2013). Quantifying the dissolved silicon, or silicic acid $\left(\mathrm{Si}(\mathrm{OH})_{4}\right)$, concentration of upwelling waters is essential if we are to understand the distribution and growth of diatoms in surface waters and so the drawdown on atmospheric carbon dioxide (Hendry and Brzezinski, 2014). The silicon isotope $\left(\delta^{30} \mathrm{Si}\right)$ and oxygen isotope $\left(\delta^{18} \mathrm{O}\right)$ compositions of biogenic silica have been used to infer modern nutrient cycling, past nutrient supply and utilisation, and hydrological cycling. Whilst the isotope composition of diatom opal has been used widely to understand past surface conditions (Leng et al., 2009), the chemical composition of benthic dwelling, deep-sea sponge opal holds the potential to reveal insights into bottom water conditions.

Both silicon and oxygen are present in three stable isotopes: ${ }^{28} \mathrm{Si}(\sim 92.2 \%),{ }^{29} \mathrm{Si}(\sim 4.7 \%)$, and ${ }^{30} \mathrm{Si}(\sim 3.1 \%)$; 
and ${ }^{16} \mathrm{O}(\sim 99.7 \%),{ }^{17} \mathrm{O}(\sim 0.04 \%)$, and ${ }^{18} \mathrm{O}(\sim 0.2 \%)$ respectively (http://www.nndc.bnl.gov/chart/). The per mille silicon isotopic composition is expressed relative to the NIST standard, NBS 28, according to Eq. (1), and similarly the oxygen isotopic composition is expressed relative to VSMOW, according to Eq. (2):

$$
\begin{aligned}
& \left(\frac{\left({ }^{30} \mathrm{Si} /{ }^{28} \mathrm{Si}\right)_{\text {sample }}}{\left.{ }^{\left({ }^{0} \mathrm{Si} /{ }^{28} \mathrm{Si}\right)_{\mathrm{NBS} 28}}-1\right) \cdot 1000}\right. \\
& \left(\frac{\left({ }^{18} \mathrm{O} /{ }^{16} \mathrm{O}\right)_{\text {sample }}}{\left({ }^{18} \mathrm{O} /{ }^{16} \mathrm{O}\right)_{\text {VSMOW }}}-1\right) \cdot 1000 .
\end{aligned}
$$

Recent work has shown that $\delta^{30} \mathrm{Si}$ of a wide range of deepsea sponges from different ocean basins appears reflects the availability of dissolved silicon (silicic acid $\left[\mathrm{Si}(\mathrm{OH})_{4}\right]$ ) during growth, with minimal impact from temperature, $\mathrm{pH}$, and (to date, and in few studies) no systematic speciesdependent fractionation (Hendry and Robinson, 2012; Wille et al., 2010). With sponge spicules ubiquitous in sediments throughout the ocean and with degradation occurring at rates that are orders of magnitude slower than those for diatoms and other siliceous organisms (Maldonado et al., 2005, 2012), there is significant potential for spicules to be used as a proxy for past ocean conditions. Whilst a number of papers have explored the use of $\delta^{30} \mathrm{Si}$ in sponges (e.g. Ellwood et al., 2010; Hendry et al., 2014), there is still scatter in the calibration of the $\delta^{30} \mathrm{Si}-\mathrm{Si}(\mathrm{OH})_{4}$ relationship, with the sources of variability poorly understood. Likewise, little is known about the sponge spicule silica $\delta^{18} \mathrm{O}$, although it is likely impacted by biological factors (Matteuzzo et al., 2013) that cause systematic offsets when compared to diatom silica $\delta^{18} \mathrm{O}$ (Snelling et al., 2014). Here, we investigate the impact of derived biomineralisation mechanisms that could be responsible for variations in silicon and oxygen isotope fractionation in sponges using a carnivorous sponge specimen from the Southern Ocean as a case study.

\subsection{Sponges and sponge biomineralisation}

Sponges (Porifera) are sessile filter-feeding animals. Their body plan has evolutionarily been shaped to optimise the feeding function, evolving an architectural design that, in general, is shared by the four major sponge lineages (Demospongiae, Hexactinellida, Homosclerophorida, and Calcarea). The anatomical archetype of a sponge is a vaseshaped or oblate body crossed by a system of aquiferous canals that communicate to the outside at both ends, and through which a current of environmental water flows, transporting bacteria and dissolved compounds that nourish the sponge, as well as oxygen and waste products. The histological archetype of a sponge consists of two epithelial layers of flattened cells (pinacocytes), an external layer that forms the wall of the body, and an internal layer that forms the wall of the aquiferous canals. Between the epithelium of the canals and the external epithelium, there is a mesenchyme-like zone that is rich in collagen and is populated by different groups of mobile amoeboid cells. The spicules (i.e. siliceous or calcareous skeletal pieces that give structural support to these often soft-bodied organisms) are also produced and assembled together by cells (i.e. sclerocytes) in the mesenchymelike zone. The aquiferous canals include chamber-shaped expansions, in which the walls are coated not by pinacocytes but choanocytes that is pseudocylindrical cells possessing a flagellum surrounded by a collar of microvilli at the distal pole. These cells phagocytose picoplankton from the water passing through the chambers; they are the most distinctive feature of the phylum Porifera.

However, a group of demosponges, currently mainly classed in the family Cladorhizidae (Order Poecilosclerida), have evolved a carnivorous habit (Vacelet, 2006), thought to be an adaptation to the nutrient-poor environments in which they inhabit, where a "sit-and-wait" predatory strategy is beneficial because of the low energy expenditure between rare feeding opportunities (Vacelet and Duport, 2004; Vacelet, 2007). Carnivorous sponges are usually associated with low-nutrient mid-basin areas of the deep-sea (the deepest recorded at $8840 \mathrm{~m}$ but a few are found around $100 \mathrm{~m}$ depth in high latitudes and some species have also been found in shallow sublittoral and littoral caves in the Mediterranean, where they are thought to have colonised from deepwater populations (Aguilar et al., 2011; Bakran et al., 2007; Chevaldonné et al., 2014; Lopes et al., 2012; Vacelet, 2006, 2007). These carnivorous sponges show not only an unusual internal body organisation lacking choanocytes and aquiferous canals, but also a convergence towards characteristic morphological adaptations including an upright stalked body, with branches, and feather-like or balloon-like lateral expansions to enhance encounter rates with prey. Carnivorous sponges have developed either rhizoid-like or bulbous bases for holding their erect bodies on muddy and hard substrates respectively (Vacelet, 2007).

The family Cladorhizidae, despite being relatively small (7 genera, 140 spp.; Porifera World Database, September 2014), has a moderate diversity of spicules. In these sponges, the silica spicules are needed not only to provide skeletal support to the body, but also to capture prey. Their relatively small bodies (rarely taller than $10 \mathrm{~cm}$ ) usually have an internal, central skeletal core (axial skeleton) made by a bundle of highly packed needle-like spicules, typically shorter than $700 \mu \mathrm{m}$ each, and with one or both ends being pointed (i.e. monactinal or diactinal megascleres). From this axial skeleton, radiating spicule tracts diverge (extra-axial skeleton) to core either the branches or any of the other types of lateral processes occurring in the body, depending on the genera and species. In addition to this main supportive skeleton, there are thousands of smaller $(<100 \mu \mathrm{m}$; microscleres) hook-like spicules, being either simple hooks (sigmas) or tooth-bearing hooks (chelae). These are scattered through the internal mesenchyme-like tissue and, more importantly, 
also at the external epithelia, where they project part of their hooking structure out of the body to capture small crustaceans that may contact the external sponge surface. Some of these sponge species have additional microscleric spicules to reinforce the skeleton, but very few carnivorous species and in only the genera Asbestopluma (Family Cladorhizidae), Euchelipluma (Family Guitarridae), and Esperiopsis (Family Esperiopsidae) - have been described having hypersilicified spicules (called desmas). Desmas are usually confined to the basal body region, probably to strengthen the area through which the sponge attaches to the substrate (Vacelet, 2007).

Because carnivorous sponges lack the aquiferous system that conventionally transports ambient seawater into the sponge body and because the isotope signal of their silica spicules has never been assessed before, it is compelling to examine whether silicon fractionation values in carnivorous sponges differ from those measured in the more conventional, filter-feeding sponges. As carnivorous sponges are typically constrained to bathyal habitats (Vacelet, 2007), their skeletons may turn into a good tool to infer traits of deep regional water masses. The recent collection of a new species of desma-bearing cladorohizid to be formally described in the genus Asbestopluma (Goodwin et al., 2014) has provided an unparalleled opportunity to investigate $\delta^{30} \mathrm{Si}$ and $\delta^{18} \mathrm{O}$ of its silica spicules.

\section{Methods}

\subsection{Specimen}

Specimen DH19-2 (Asbestopluma sp.) was recovered by Hein Dredge from Burdwood Bank (1500-1530m water depth, $54^{\circ} 45^{\prime} \mathrm{S}, 62^{\circ} 16^{\prime} \mathrm{W}$ ) in the Atlantic sector of the Southern Ocean from the R/V Nathaniel B. Palmer in 2011 (National Science Foundation NBP1103). The specimen was photographed and dried for transportation. Temperature, salinity, and $\mathrm{Si}(\mathrm{OH})_{4}$ concentrations of the ambient water are estimated as $2.5-3{ }^{\circ} \mathrm{C}, 34.5$, and $60 \mu \mathrm{M}$, respectively (from on-board measurements and literature data available at www.eWOCE.org).

The specimen has an upright, moderately branching form (Fig. 1). The basal body portion contains internally interlocked desmas (Fig. 2a and b), externally surrounded by layer of microscleric acanthotylostrongyles (Fig. 2b) and scarce sigmas. It is worth noting that the abundance of desmas decreases significantly from the basal body portion to the branch tips and that the acanthotylostrongyles occur exclusively at basal portion of the sponge. Further up the axis, the stem is cored by large smooth monoactines (styles), with smaller styles and diactines with rounded ends (anisostrongyles) outside this core, sigmas and chelae microscleres are also present (Fig. 2c). Desmas become less frequent with increasing distance from the base (with desmas representing approximately $90 \%$ of the spicules from

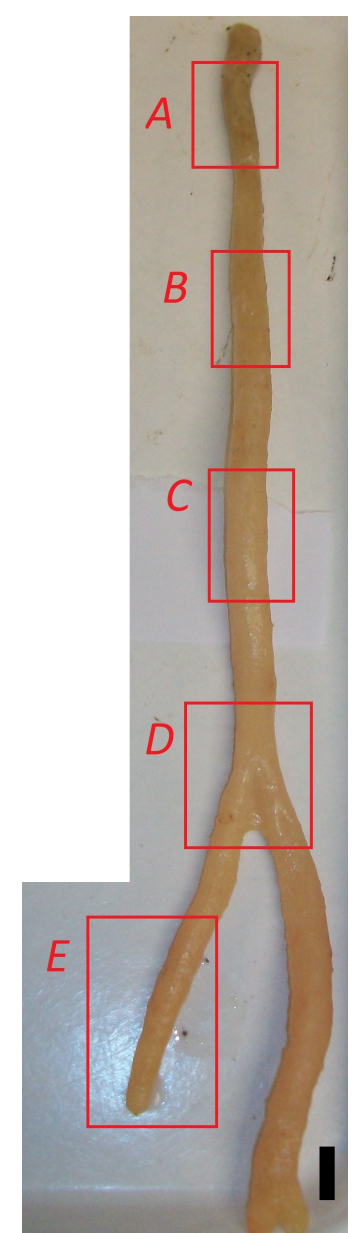

Figure 1. Specimen DH19-2, Asbestopluma sp. Scale bar shows $1 \mathrm{~cm}$. Red boxes show subsampling sections A-E.

A, $50 \%$ from B, $40 \%$ from $C$ and less than $25 \%$ from $\mathrm{D}$ and E) so that at the growth tips, there are only styles, sigma and chelae.

\subsection{Sample preparation}

Five sponge tissue samples (a to e) were taken along the body length of the specimen, that is, at increasing distance from the attachment point, covering from the base to the branch tip (Fig. 1). Samples were cleaned for organic matter by heating to $80^{\circ} \mathrm{C}$ in $30 \%$ hydrogen peroxide for at least an hour and rinsing thoroughly in deionised water at least three times. At this stage, for each tissue sample, two skeletal subsamples were obtained from (1) the spicules of the axial skeleton (axial or "internal" samples), and (2) the spicules of the radiating skeleton and the external epithelium (extra-axial or "external" samples). The subsamples were then heated to $80^{\circ} \mathrm{C}$ in trace metal grade concentrated nitric acid for at least an hour, and rinsed thoroughly in $18 \mathrm{M} \Omega \mathrm{cm}$ Milli-Q water at least three times. Standards and samples were prepared by alkaline fusion with sodium hydroxide pellets, acidified with 


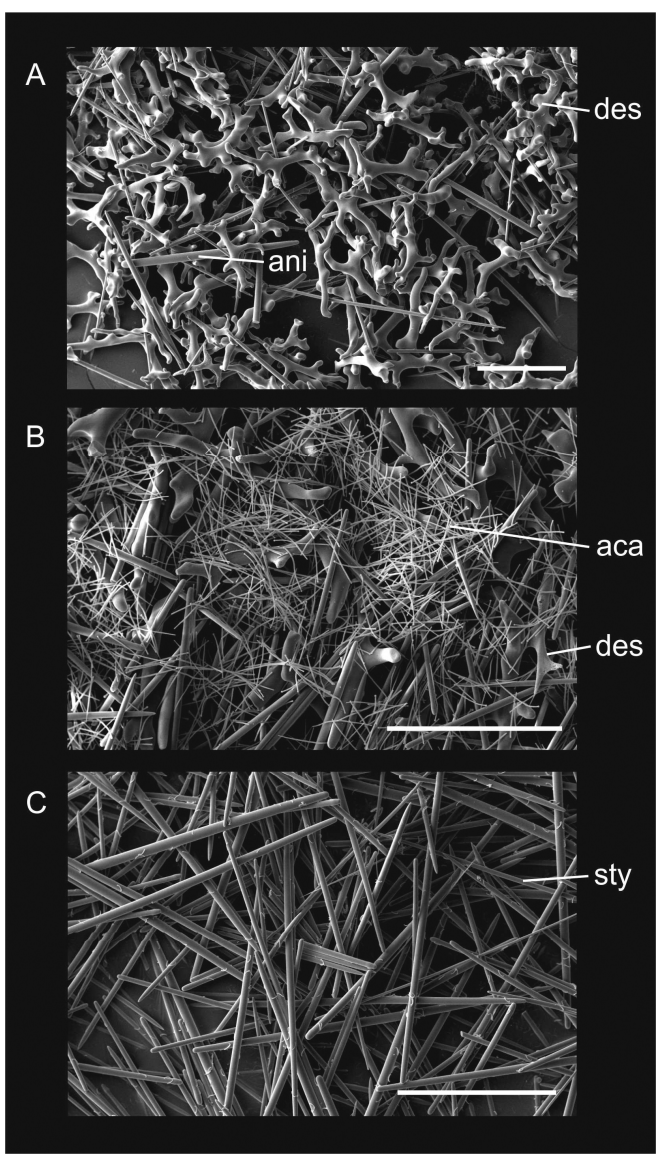

Figure 2. Scanning electron microscope images of subsamples from DH19-2 Asbestopluma sp. (a) internal framework section A, near the base; (b) external section A, near the base; (c) internal section E, the growing tip abbreviations: des = desma, ani = anisostrongyles, $\mathrm{aca}=$ acanthotylostrongyles, sty $=$ styles.

ultra-clean nitric acid (Optima), and purified using cation exchange resin (Georg et al., 2006). Note that heating opal to $80^{\circ} \mathrm{C}$ during the organic matter removal process does not result in additional fractionation of spicule silicon isotopes (Hendry et al., 2011). Although there is no available information specifically about modern sponge spicules, heating samples of phytolith opal to $80^{\circ} \mathrm{C}$ during cleaning does not result in additional fractionation of oxygen isotopes (Crespin et al., 2008). One study suggests that heating diatom opal to over $60^{\circ} \mathrm{C}$ results in a potential offset in $\delta^{18} \mathrm{O}$ as a result of dissolution (Crespin et al., 2008). However, the $\delta^{18} \mathrm{O}$ values from 70 and $90^{\circ} \mathrm{C}$ from this study were within analytical error of the values of diatoms treated at $60^{\circ} \mathrm{C}$. Furthermore, heating of diatom opal to $70^{\circ} \mathrm{C}$ using different cleaning methods does not result in measurable changes in $\delta^{18} \mathrm{O}$ (Tyler et al., 2007). Heating to higher temperatures of $80-90^{\circ} \mathrm{C}$ is routine in downcore spicule opal $\delta^{30} \mathrm{Si}$ analyses (e.g. Snelling et al., 2014).

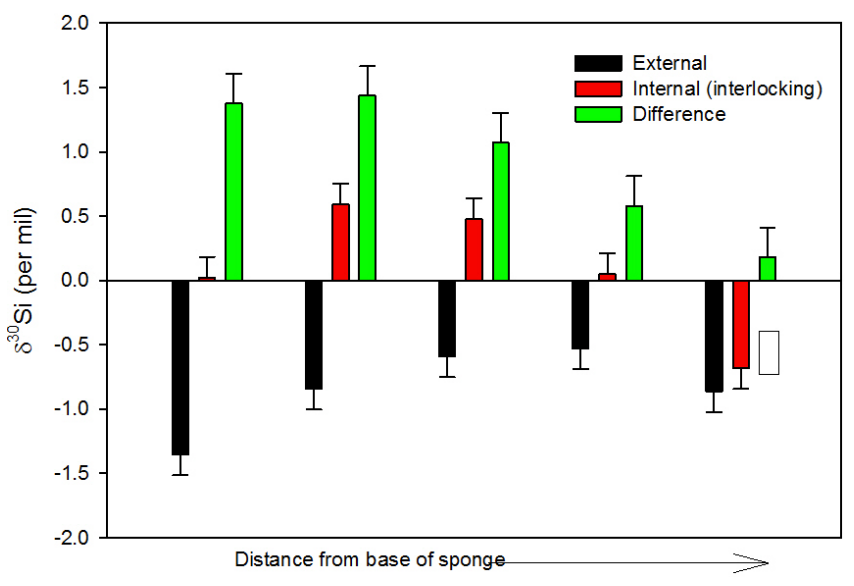

Figure 3. $\delta^{30} \mathrm{Si}$ values for subsamples of DH19-2. Red bars show the internal interlocking framework, black bars show the external loose spicules, and green bars show the difference between the internal and external spicules. Hollow rectangular symbol shows the isotopic composition of individually picked and cleaned styles from the growing tip. Error bars show external reproducibility from replicate standard measurements (2SD).

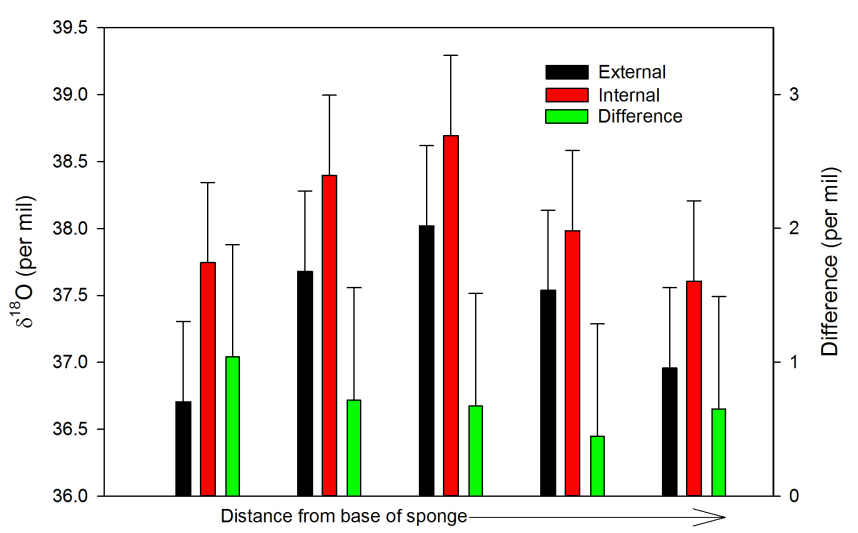

Figure 4. $\delta^{18} \mathrm{O}$ values for subsamples of DH19-2. Red bars show the internal interlocking framework, black bars show the external loose spicules, and green bars show the difference between the internal and external spicules. Error bars show external reproducibility from replicate standard measurements (2SD).

\subsection{Silicon isotope analysis}

The samples were analysed for silicon isotope ratios $\left({ }^{29} \mathrm{Si} /{ }^{28} \mathrm{Si},{ }^{30} \mathrm{Si} /{ }^{28} \mathrm{Si}\right)$ using a Thermo Neptune MultiCollector Inductively Coupled Plasma Mass Spectrometer (MC-ICP-MS) at Bristol University (Bristol Isotope Group). The isotope ratios were measured using 20 cycles per block. Machine blanks were monitored, and were $<1 \%$ of the signal on ${ }^{28} \mathrm{Si}$. Mass bias and matrix effects were corrected using standard-sample bracketing and internal Mg-doping (Cardinal et al., 2003; Hendry and Robinson, 2012). Silicon and magnesium intensities were intensity matched within $10 \%$ (typically $<5 \%$ ). The results are reported as $\delta^{30} \mathrm{Si}$ val- 
ues relative to the standard NBS28 (RM8546). Analysis of "diatomite" during the study yielded a mean $\delta^{30} \mathrm{Si}$ value of $-1.25 \%$ ( $( \pm 0.182 \mathrm{SD}, n=70)$; "big-batch" yielded a mean $\delta^{30} \mathrm{Si}$ value of $-10.67 \%$ ( $\left.\pm 0.082 \mathrm{SD}, n=3\right)$ (Reynolds et al., 2007). Repeat analyses of sponge standard LMG08 (Hendry and Robinson, 2012) during each run were used to assess long-term external reproducibility, and yielded a mean $\delta^{30} \mathrm{Si}$ value of $-3.41 \%$ over 6 months $( \pm 0.162 \mathrm{SD}, n=31)$. $\delta^{29} \mathrm{Si} / \delta^{30} \mathrm{Si}$ for all samples and standards was $\sim 0.51$, consistent with mass-dependent fractionation (Cardinal et al., 2003).

\subsection{Oxygen isotope analysis}

Aliquots of spicule samples were analysed for oxygen isotope ratios $\left({ }^{18} \mathrm{O} /{ }^{16} \mathrm{O}\right)$ following a step-wise fluorination procedure (Leng and Sloane, 2008) verified through an interlaboratory calibration exercise (Chapligin et al., 2011). Samples were outgassed in nickel reaction vessels and reacted with $\mathrm{BrF}_{5}$ for $6 \mathrm{~min}$ at $250^{\circ} \mathrm{C}$ to remove all $\mathrm{Si}-\mathrm{OH}$ bonds. Oxygen from $\mathrm{Si}-\mathrm{O}-\mathrm{Si}$ bonds was subsequently released by reaction with further reagent overnight at $550^{\circ} \mathrm{C}$ before being converted and collected as $\mathrm{CO}_{2}$. Oxygen isotope measurements were made on a Finnigan MAT 253 with values converted to the VSMOW scale using the run laboratory diatom standard $\mathrm{BFC}_{\text {mod }}$ calibrated against NBS28. Repeat analysis of $\mathrm{BFC}_{\mathrm{mod}}$ indicates reproducibility is $0.6 \%$ (2SD) (Leng and Sloane, 2008).

\subsection{Electron microscopy}

Scanning electron microscopy (SEM) was used to describe the siliceous skeleton at the various body regions. An aliquot of spicules from each subsample was mounted onto an SEM aluminium stub, coated by gold sputtering and imaged using a HITACHI S-3500N Scanning Electron Microscope. To document the presence/absence of an axial canal at the core of the various spicules types, $1 \mathrm{~mm}^{3}$ sponge tissue samples were collected, placed onto a glass cover slip and subsequently cleaved multiple times to fracture the spicules using a scalpel blade under a dissecting scope. The cover slip with the cleaved tissue was placed onto a glass slide and, to eliminate the organic matter from the silica skeleton, three drops of concentrate nitric acid were added on the tissue sample while maintaining the slide above the flame of an alcohol burner. After the boiling and evaporation of acid, new acid drops were added and the operation was repeated several times until corroboration through a light microscope that the silica spicules were externally cleaned from organic remains, before rinsing three times in Milli-Q water. The slip bearing the cleaned, fractured spicules was mounted onto an SEM aluminium stub and coated by gold sputtering for further observation of fracture planes and axial canals using a HITACHI TM300 Scanning Electron Microscope.
Table 1. Stable isotope results for DH19-2 Asbestopluma sp. specimen.

\begin{tabular}{lllll}
\hline & \multicolumn{2}{c}{ Internal } & \multicolumn{2}{c}{ External } \\
Subsample & $\delta^{30} \mathrm{Si}(\% \circ)$ & $\delta^{18} \mathrm{O}(\% \circ)$ & $\delta^{30} \mathrm{Si}(\% \circ)$ & $\delta^{18} \mathrm{O}(\% \circ)$ \\
\hline $\mathrm{A}$ & +0.02 & +37.74 & -1.35 & +36.71 \\
$\mathrm{~B}$ & +0.59 & +38.4 & -0.84 & +37.68 \\
$\mathrm{C}$ & +0.48 & +38.69 & -0.59 & +38.02 \\
$\mathrm{D}$ & +0.05 & +37.98 & -0.53 & +37.54 \\
$\mathrm{E}$ & -0.68 & +37.61 & -0.86 & +36.96 \\
\hline
\end{tabular}

\subsection{Results}

\subsubsection{Silicon isotopes}

The average $\delta^{30} \mathrm{Si}$ value for the cladorhizid DH19-2 was $-0.37 \%$, but values ranged from -1.35 to $+0.59 \%$, with an overall range of $1.94 \%$ (Table 1; Fig. 3). These values fall within the total range of modern sponge ${ }^{30} \mathrm{Si}$ measurements in the literature (e.g. Hendry and Robinson, 2012). Since previous studies have found no discernible variation within an individual (Hendry et al., 2010, 2011), this is an unprecedented variability within a single specimen, and represents approximately $40 \%$ of the total range of isotope values for existing calibrations ( 5\%o) (Hendry and Robinson, 2012). The external spicules were significantly and consistently isotopically lighter than the internal interlocking spicules. The external and internal spicules became isotopically heavier and lighter respectively along the axis, such that the difference between the internal and external spicules decreased away from the base of the specimen (from approximately $1.4 \%$ at a to approximately $0.1 \%$ at e; Fig. 3 )

\subsubsection{Oxygen isotopes}

The average $\delta^{18} \mathrm{O}$ value for DH19-2 was $+37.7 \%$, ranging from +36.7 to $+38.7 \%$ (Figure 4 ), giving a range of $2 \%$ o. The $\delta^{18} \mathrm{O}$ of the marine specimen in this study is significantly heavier than values obtained for freshwater sponge spicules (approximately +22 to $+30 \%$ o). The fractionation factor $\left(\Delta \delta^{18} \mathrm{O}_{\text {silica-seawater }}\right)$ for the marine sponge $(+36$ to $+39 \%$ ) was greater than that of freshwater sponges $(+28 \%)$ (Matteuzzo et al., 2013). The variation within the one individual from this study compares to an entire range of $\delta^{18} \mathrm{O}_{\text {water }}$ of less than $0.8 \%$ and potential temperature variations of $\sim 5^{\circ} \mathrm{C}$ across the Drake Passage (Meredith et al., 1999 ), and represents nearly half of the $5 \%$ variations found in a downcore sponge spicule $\delta^{18} \mathrm{O}$ record from Pliocene sediments (Snelling et al., 2014). The external spicules were consistently isotopically lighter than the internal interlocking spicules, although the difference between them ( 0.4 to $1 \%$ ) is approximately the same as the analytical error (2SD of $0.6 \%$ ). The trend in $\delta^{18} \mathrm{O}$ along the axis of the specimen is less clear than for $\delta^{30} \mathrm{Si}$ : both the external and internal spicules because isotopically heavier from $\mathrm{A}$ to $\mathrm{C}$, and 
then isotopically lighter from $\mathrm{C}$ to $\mathrm{E}$. There is also a positive correlation between $\delta^{30} \mathrm{Si}$ and $\delta^{18} \mathrm{O}(r=0.88, p=0.001$, $n=10)$.

\subsection{Discussion}

\subsubsection{Silicon isotopes and internal fractionation}

The large variation in both isotope systems within the studied individual relates to a differential distribution of the spicule types along the sponge body (i.e. distance from sponge base), and also to differences in the abundance of given spicule types between the internal (axial) and external (extra-axial) body regions. The external basal skeleton (i.e. mostly acanthotylostrongyles) has the most isotopically light (negative) $\delta^{30} \mathrm{Si}$ that lies close to the existing $\delta^{30} \mathrm{Si}-\mathrm{Si}(\mathrm{OH})_{4}$ calibration curve (Fig. 5). The internal basal skeleton (i.e. mostly desmas) has a very isotopically heavy (positive) $\delta^{30} \mathrm{Si}$ signature compared to that of the external spicules, which may relate to the presence of desma spicules.

The desmas of this carnivorous sponge have an unusual formation mechanism compared to other megascleric demosponge spicules. Nearly all types of megascleric spicule, including most desmas, show an internal or "axial" canal (Fig. 6a). This canal originally harbours a filament of the enzymatic protein silicatein (Shimizu et al., 1998), responsible for initiating the polymerisation of biogenic silica, the growth of which starts intracellularly through an enzymatically guided polycondensation of dissolved silicon. The term "desmas" represents a large variety of phylogenetically unrelated spicule morphologies, which only share the feature of being massive, relatively irregular skeletal pieces produced by hypersilicification, and may or may not possess an axial canal. How and where the hypersilicification of desmas is achieved remains poorly understood. In all cases described to date, the desmas in carnivorous sponges are anaxial, that is, lack axial canals (Fig. 6b). The absence of an axial canal indicates that their silicification does not involve an initial intracellular, enzyme-guide silica polymerisation. Consequently, these anaxial desmas must grow via a mechanism different from that taking place in other demosponge spicules, which may account for their distinctive silicon and oxygen isotopic composition. This idea is in agreement with previous findings indicating that some cellular mechanisms for spicule silicification may have evolved independently in different sponge lineages (Maldonado and Riesgo, 2007). The level at which the secondary hypersilicification step of desmas could also contribute, if any, to their isotope signal remains unknown, and further study into the potential differences in the isotopic signal between desmas with and without axial canals is required.

The decreasing abundance of desmas with increasing distance from the sponge base is at least one of the plausible factors responsible for the within-sponge variation in isotope compositions observed in this study. We suggest that
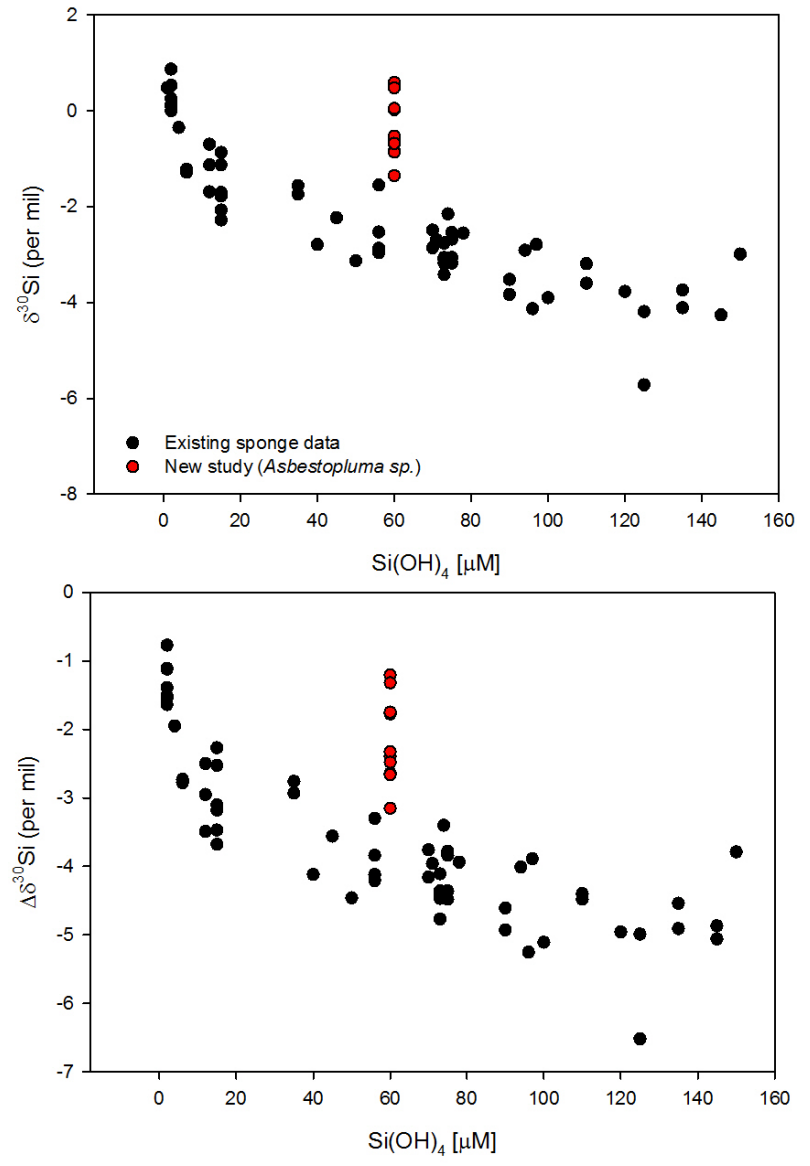

Figure 5. Comparison of $\delta^{30} \mathrm{Si}$ and $\Delta \delta^{30} \mathrm{Si}\left(=\delta^{30} \mathrm{Si}_{\text {sponge }}-\right.$ $\delta^{30} \mathrm{Si}_{\text {seawater }}$ ) results from DH19-2 Asbestopluma sp. (red symbols) and existing calibration (black symbols). Data for sponge $\delta^{30} \mathrm{Si}$ and references for seawater $\delta^{30} \mathrm{Si}$ from Hendry et al. (2010), Hendry and Robinson (2012), and Wille et al. (2010).

the likely extracellular silicification of these desmas could result in kinetic fractionation of silicon isotopes. It should also be noted that the external basal spicules (i.e. the acanthotylostrongyles), although forming the "best fit" to the existing $\delta^{30} \mathrm{Si}-\mathrm{Si}(\mathrm{OH})_{4}$ calibration, are still outside of analytical error of the calibration curve, and this offset could be explained by some desma contamination (Fig. 2b).

Further up the axis away from the base, the extra-axial styles have a higher $\delta^{30} \mathrm{Si}$ moving further away from the existing $\delta^{30} \mathrm{Si}-\mathrm{Si}(\mathrm{OH})_{4}$ calibration curve (Fig. 5), which is then lower again towards the growing tip. This does not reflect contamination from microscleres (i.e. sigmas and chelae), as individually picked and cleaned styles are within analytical uncertainty $( \pm 0.15 \%$ o) of the bulk measurement (see white box on Fig. 3). Although the internal styles also become isotopically enriched, the difference between the internal and external spicule $\delta^{30} \mathrm{Si}$ declines up the axis, most likely because of a decline in the number of desmas. 


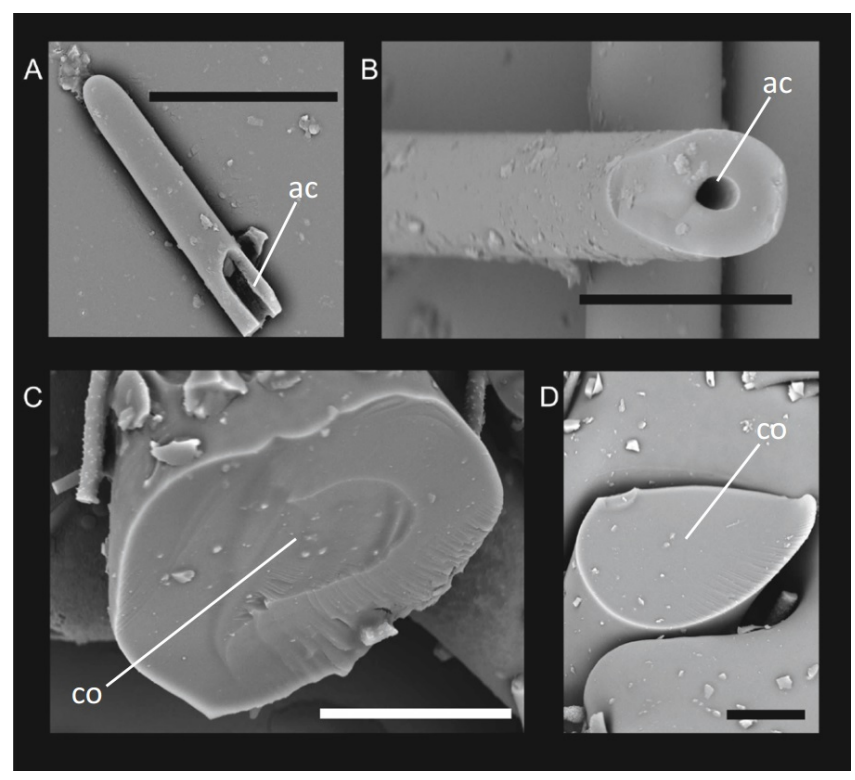

Figure 6. Scanning electron microscope images of fracture plane of Asbestopluma sp. spicules. (a and b) Megascleric styles showing the internal axial canal (ac) (scale bar $30 \mu \mathrm{m})$. (c and d) Core area (co) of anaxial desmas of the cladorhizid DH19-2 showing the absence of axial canal (scale bar $20 \mu \mathrm{m}$ ).

There are also two alternative, but probably less plausible, explanations for the large intra-individual isotopic variation along the body axis. One is that this sponge grows extremely slowly (over centuries) in the deep-sea environment. If so, it could be that during the first decades of its life, what is now the basal body portion was exposed to a water mass with temperature and silicic acid concentration different from present, progressively changing overtime towards the current values and impacting accordingly the isotope signal during sponge growth. A second possibility is that this sponge grows very rapidly. If so, the basal portion could have been formed during an episodic input of seawater with abnormal silicic acid concentration and temperature, compared to the ambient conditions during the subsequent growth. Because virtually nothing is known about the longevity and growth rate of these sponges, these ideas remain mere speculation.

Could the heavy silicon isotope bias be a consequence of the absence of an aquiferous system in the carnivorous sponge? Given that the aquiferous system usually allows the circulation of ambient seawater throughout the body, the loss of this system could result in internal silicon isotope fractionation as the isotopes in the aqueous component becomes progressively heavier due to precipitation of silica in a closed system. This process would explain not only the offset between the external and internal spicules but also the trends along the length of the sponge stem. Again, nothing is known about how the dissolved silicon molecules are transported into the body by these sponges or about the average replenishment rate for dissolved silicon within the internal tissues. Nevertheless, if a simplified silicon isotope fractionation model is formulated, ignoring the impact of desmas and assuming a variable silicon isotopic fractionation during sponge growth according to the core top spicule calibration of Hendry and Robinson (2012), we can examine the impact of an isotopically closed system on changes in spicule composition with cellular silicon utilisation (Fig. 7). This simplified model suggests that relatively small degrees of cellular silicon utilisation (less than $30 \%$ ) could result in heavier $\delta^{30} \mathrm{Si}$ observed up the axis of the Asbestopluma sp. specimen. A higher rate of dissolved silicon replenishment and a faster sponge growth rate could explain the return to lighter isotopic compositions at the growing tips.

\subsubsection{Oxygen isotopes and additional fractionation processes}

The positive correlation that we find within one individual between $\delta^{30} \mathrm{Si}$ and $\delta^{18} \mathrm{O}$ indicates that there may be some shared mechanisms behind fractionation of the two isotope systems, at least in Asbestopluma. There is a similar systematic offset between the external and internal spicules in $\delta^{18} \mathrm{O}$ as for $\delta^{30} \mathrm{Si}$ values, suggesting that the unusual silicification process that results in desma formation may fractionate oxygen isotopes in a similar manner to silicon. However, the along-axis trend is less clear in the $\delta^{18} \mathrm{O}$ than $\delta^{30} \mathrm{Si}$, suggesting desmas cause a smaller bias in oxygen isotope systematics than for silicon. Furthermore, there is no significant along-axis decrease in $\delta^{18} \mathrm{O}$ in the internal spicules, as observed for $\delta^{30} \mathrm{Si}$, suggesting that any internal fractionation of oxygen isotopes is less pronounced and within the analytical uncertainty.

Additional processes active at the surface of the sponge spicule silica may also have an influence on both the silicon and oxygen isotope values, including precipitation processes and dissolution. There is some evidence from one laboratory study for a silicon isotope fractionation during dissolution of diatom opal (Demarest et al., 2009), which is not supported by more recent laboratory and field studies (Egan et al., 2012; Wetzel et al., 2014). Although there is potential for kinetic fractionation of oxygen during dissolution and reprecipitation of silica (Crespin et al., 2008; Dodd and Sharp, 2010), further work is required to investigate whether fractionation of either silicon or oxygen isotopes occurs during the dissolution of sponge spicules, or by any additional surface precipitation processes.

\section{Implications for palaeoclimate and outlook}

This first study of within-sponge differential fractionation has a number of implications for biomineralisation and the use of isotope proxies for reconstructing past nutrient conditions. Firstly, our findings suggest that internal non- 


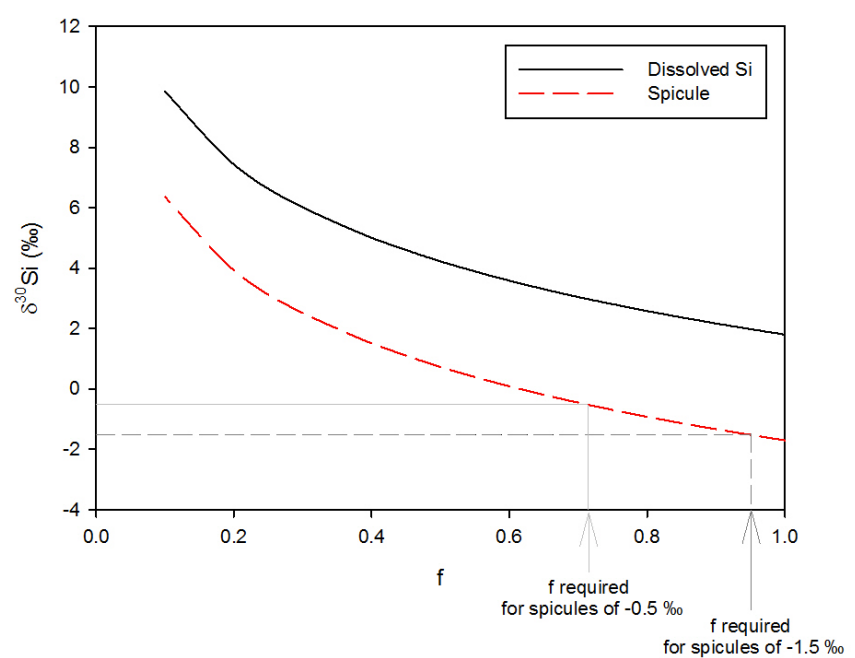

Figure 7. Sponge fractionation model for internal $\mathrm{Si}$ in an isotopically closed system. We assume a variable fractionation factor $\epsilon^{\prime}$ that approximates $\Delta \delta^{30} \mathrm{Si}$ from the core top spicule calibration curve of Hendry and Robinson (2012): $\Delta \delta^{30} \mathrm{Si}=-6.54+$ $\left(270 /\left(53+\left[\mathrm{Si}(\mathrm{OH})_{4}\right]\right)\right)$. The internal dissolved $\mathrm{Si}$ will fractionate according to $\delta^{30} \mathrm{Si}(\mathrm{OH})_{4 \text { internal }}=\delta^{30} \mathrm{Si}(\mathrm{OH})_{4 \text { initial }}+\epsilon^{\prime} \cdot \ln (f)$. Where $f$ is the fraction of dissolved Si left available internally. The $\delta^{30} \mathrm{Si}$ of the spicules that form from this silicon depleted fluid is then given by $\delta^{30} \mathrm{Si}=\delta^{30} \mathrm{Si}(\mathrm{OH})_{4 \text { internal }}+\epsilon^{\prime}$.

equilibrium fractionation of silicon isotopes in sponges can occur, depending on silicic acid replenishment rates in the internal tissues, which could explain some of the scatter in the $\delta^{30} \mathrm{Si}-\mathrm{Si}(\mathrm{OH})_{4}$ calibration plot (Hendry and Robinson, 2012). Internal fractionation could also impact sponge $\delta^{18} \mathrm{O}$, but less severely. We suggest that the anaxial desmas of this and probably other carnivorous sponges have a different mode of silicification causing an unusual isotopic signature in their biogenic silica.

Secondly, this study highlights the need for caution when preparing samples in order to compile robust palaeoclimate archives. A large number of spicules should be picked for such archives in order to "average" out variations caused by kinetic fractionation in Cladorhizid sponges, which cannot be readily distinguished using light microscopy. Furthermore, desma formation may result in very different fractionation behaviour. However, desmas are morphologically distinct, and should be excluded from proxy measurements for palaeoclimate applications until further studies have been completed to assess the level at which these spicules result in isotopic bias. Whether axial and anaxial desmas can provide an independent complementary proxy to corroborated trends inferred from the "conventional" silica spicules is a possibility that needs to be explored in future studies.

Acknowledgements. The authors would like to thank C. D. Coath (Bristol) for assistance with mass spectrometry, L. Robinson (Bristol), R. Waller (Maine), and the captain and crew of the R/V
Nathaniel B. Palmer. Samples were processed in the laboratories at Cardiff University with thanks to R. Perkins. SEM images were taken at the University of Bristol with the assistance of S. Kearns, B. Buse, and A. Anton-Stephens, and at CEAB-CSIC, Blanes. This work was funded by the National Science Foundation (grants 0944474, 0636787 and 1029986), the Leverhulme Trust (Research Grant RPG-2012-615); K. R. Hendry is funded by the Royal Society. M. Maldonado is funded by the Spanish Ministry of Innovation and Competitiveness (CTM2012-37787). C. Goodwin is a research associate at Queen's University Marine Laboratory, Portaferry. The authors would like to thank the two anonymous reviewers for their constructive comments.

Edited by: A. Shemesh

\section{References}

Aguilar, R., Correa, M. L., Calcinai, B., Pastor, X., and De la Torriente, A.: First records of Asbestopluma hypogea Vacelet and Boury-Esnault, 1996 (Porifera, Demospongiae Cladorhizidae) on seamounts and in bathyal settings of the Mediterranean Sea, Zootaxa, 2925, 33-40, 2011.

Bakran-Petricioli, T., Vacelet, J., Zibrowius, H., Petricioli, D., and Chevaldonné, P.: New data on the distribution of the "deepsea" sponges Asbestopluma hypogea and Oopsacas minuta in the Mediterranean Sea, Mar. Ecol., 28, 10-23, 2007.

Cardinal, D., Alleman, L. Y., de Jong, J., Ziegler, K., and Andre, L.: Isotopic composition of silicon measured by multicollector plasma source mass spectrometry in dry plasma mode, J. Anal. Atom. Spectrom., 18, 213-218, 2003.

Chapligin, B., Leng, M. J., Webb, E., Alexandre, A., Dodd, J. P., Ijiri, A., Andreas Lücke g, Shemesh, A., Abelmann, A., Herzschuh, U., Longstaffe, F. J., Meyer, H., Moschen, R., Okazaki, Y., Rees, N. H., Sharp, Z. D., Sloane, H. J., Sonzogni, C., Swann, G. E. A., Sylvestre, F., Tyler, J. J., and Yam, R.: Inter-laboratory comparison of oxygen isotope compositions from biogenic silica, Geochim. Cosmochim. Ac., 75, 7242-7256, 2011.

Chevaldonné, P., Pérez, T., Crouzet, J. M., Bay-Nouailhat, W., Bay-Nouailhat, A., Fourt, M., Almòn, B., Pérez, J., Aguilar, R., and Vacelet, J.: Unexpected records of "deep-sea" carnivorous sponges Asbestopluma hypogea in the shallow NE Atlantic shed light on new conservation issues, Mar. Ecol., doi:10.1111/maec.12155, 2014.

Crespin, J., Alexandre, A., Sylvestre, F., Sonzogni, C., Pailles, C., and Garreta, V.: IR laser extraction technique applied to oxygen isotope analysis of small biogenic silica samples, Anal. Chem., 80, 2372-2378, 2008.

Demarest, M. S., Brzezinski, M. A., and Beucher, C.: Fractionation of silicon isotopes during biogenic silica dissolution, Geochim. Cosmochim. Ac., 73, 5572-5583, 2009.

Dodd, J. P. and Sharp, Z. D.: A laser fluorination method for oxygen isotope analysis of biogenic silica and a new oxygen isotope calibration of modern diatoms in freshwater environments, Geochim. Cosmochim. Ac., 74, 1381-1390, 2010.

Egan, K., Rickaby, R. E. M., Leng, M. J., Hendry, K. R., Hermoso, M., Sloane, H. J., Bostock, H., and Halliday, A. N. Diatom silicon isotopes as a proxy for silicic acid utilisation: A Southern Ocean 
core top calibration, Geochim. Cosmochim. Ac., 96, 174-192, 2012.

Ellwood, M. J., Wille, M., and Maher, W.: Glacial silicic acid concentrations in the Southern Ocean, Science, 330, 1088-1091, 2010.

Georg, R. B., Reynolds, B. C., Frank, M., and Halliday, A. N.: New sample preparation techniques for the determination of $\mathrm{Si}$ isotopic composition using MC-ICPMS, Chem. Geol., 235, 95-104, 2006.

Goodwin, C., Berman, J., and Hendry, K. R.: Title to be confirmed, in preparation, 2014

Hendry, K. R., and Brzezinski, M. A.: Using silicon isotopes to understand the role of the Southern Ocean in modern and ancient biogeochemistry and climate. Quat. Sci. Rev., 89, 13-26, 2014.

Hendry, K. R. and Robinson, L. F.: The relationship between silicon isotope fractionation in sponges and silicic acid concentration: modern and core-top studies of biogenic opal, Geochim. Cosmochim. Ac., 81, 1-12, 2012.

Hendry, K. R., Georg, R. B., Rickaby, R. E. M., Robinson, L. F., and Halliday, A. N.: Deep ocean nutrients during the Last Glacial Maximum deduced from sponge silicon isotopic compositions, Earth Planet. Sci. Lett., 292, 290-300, 2010.

Hendry, K. R., Leng, M. J., Robinson, L. F., Sloane, H. J., Blusztjan, J., and Rickaby, R. E. M., Georg, R. B., and Halliday, A. N.: Silicon isotopes in Antarctic sponges: an interlaboratory comparison, Antarct. Sci., 23, 34-42, 2011.

Hendry, K. R., Robinson, L. F., McManus, J. F., and Hays, J. D.: Silicon isotopes indicate enhanced carbon export efficiency in the North Atlantic during deglaciation, Nat. Commun., 5, 05399, doi:10.1038/ncomms4107, 2014.

Leng, M. J. and Sloane, H. J.: Combined oxygen and silicon isotope analysis of biogenic silica, J. Quat. Sci., 23, 313-319, 2008.

Leng, M. J., Swann, G. E. A., Hodson, M. J., Tyler, J. J., Patwardhan, S. V., and Sloane, H. J.: The potential use of silicon isotope composition of biogenic silica as a proxy for environmental change, Silicon, 1, 65-77, 2009.

Lopes, D. A., Bravo, A., and Hajdu, E.: New carnivorous sponges (Cladorhizidae: Poecilosclerida:Demospongiae) from off Diego Ramírez Archipelago (south Chile), with comments on taxonomy and biogeography of the family, Invertebr. Syst., 25, 407-443, 2012

Maldonado, M. and Riesgo, A.: Intra-epithelial spicules in a homosclerophorid sponge, Cell Tissue Res., 328, 639-650, 2007.

Maldonado, M., Carmona, M. C., Uriz, M. J., and Cruzado, A.: Decline in Mesozoic reef-building sponges explained by silicon limitation, Nature, 401, 785-788, 1999.

Maldonado, M., Hooper, J. N. A., and Van Soest, R. W. M.: Family pachastrellidae carter, 1875, in: Systema Porifera: a Guide to the Classification of Sponges, Kluwer Academic/Plenun Publisher, New York, 141-162, 2002.

Maldonado, M., Carmona, M. C., Velásquez, Z., Puig, A., Cruzado, A., López, A., and Young, C. M.: Siliceous sponges as a silicon sink: an overlooked aspect of the benthopelagic coupling in the marine silicon cycle, Limnol. Oceanogr., 50, 799809, 2005.

Maldonado, M., Ribes, M., and Van Duyl, F. C.: Nutrient fluxes through sponges: biology, budgets, an ecological implications, Adv. Mar. Biol., 62, 114-182, 2012.
Matteuzzo, M. C., Alexandre, A., Varajão, A. F. D. C., VolkmerRibeiro, C., Almeida, A. C. S., Varajão, C. A. C., ValletCoulomb, C., Sonzogni, C., and Miche, H.: Assessing the relationship between the $\delta^{18} \mathrm{O}$ signatures of siliceous sponge spicules and water in a tropical lacustrine environment (Minas Gerais, Brazil), Biogeosciences Discuss., 10, 12887-12918, doi:10.5194/bgd-10-12887-2013, 2013.

Meredith, M. P., Grose, K. E., McDonagh, E. L., Heywood, K. J., Frew, R. D., and Dennis, P. F.: Distribution of oxygen isotopes in the water masses of Drake Passage and the South Atlantic, J. Geophys. Res., 104, 20949-20962, 1999.

Pike, J., Swann, G. E. A., Leng, M. J., and Snelling, A. M.: Glacial discharge along the west Antarctic Peninsula during the Holocene, Nat. Geosci., 6, 199-202, 2013.

Pisera, A.: Some aspects of silica deposition in lithistid demosponge desmas, Microsc. Res. Techniq., 62, 312-326, 2003.

Reynolds, B. C., Aggarwal, J., Andre, L., Baxter, D., Beucher, C., and Brzezinski, M. A., Engstrom, E., Georg, R. B., Land, M., Leng, M. J., Opfergelt, S., Rodushkin, I., Sloane, H. J., van der Boorn, S. H. J. M., Vroon, P. Z., and Cardinal, D.: An interlaboratory comparison of $\mathrm{Si}$ isotope reference materials, J. Anal. Atom. Spectrom., 22, 561-568, 2007.

Shimizu, K., Cha, J. N., Stucky, G. D., and Morse, D. E.: Silicatein alpha: cathepsin L-like protein in sponge biosilica, P. Natl. Acad. Sci. USA, 95, 6234-6238, 1998.

Snelling, A. M., Swann, G. E. A., Pike, J., and Leng, M. J.: Pliocene diatom and sponge spicule oxygen isotope ratios from the Bering Sea: isotopic offsets and future directions, Clim. Past, 10, 18371842, doi:10.5194/cp-10-1837-2014, 2014.

Tréguer, P. and De la Rocha, C. L.: The world ocean silica cycle, Ann. Rev. Marine Sci., 5, 477-501, 2013.

Tyler, J. J., Leng, M. J., and Sloane, H. J.: The effects of organic removal treatment on the integrity of $\delta^{18} \mathrm{O}$ measurements from biogenic silica, J. Paleolimnol., 37, 491-497, 2007.

Uriz, M. J., Turon, X., Becerro, M. A., and Agell, G.: Siliceous spicules and skeleton frameworks in sponges: origin, diversity, ultrastructural patterns, and biological functions, Microsc. Res. Techniq., 62, 279-299, 2003.

Vacelet, J.: New carnivorous sponges (Porifera, Poecilosclerida) collected from manned submersibles in the deep Pacific, Zool J. Linn. Soc.-Lond., 148, 553-584, 2006.

Vacelet, J.: Diversity and evolution of deep-sea carnivorous sponges, in: Porifera Research: Biodiversity, Innovation and Sustainability, edited by: Custódio, M. R., Lôbo-Hadju, G., Hadju, E., and Muricy, G., Museu Macional, Rio de Janeiro, 107$115,2007$.

Vacelet, J. and Duport, E.: Prey capture and digestion in the carnivorous sponge Asbestopluma hypogea (Porifera: Demospongiae), Zoomorphology, 123, 179-190, 2004.

Van Soest, R. W. M, Boury-Esnault, N., Hooper, J. N. A., Rützler, K., de Voogd, N. J., Alvarez de Glasby, B., Hajdu, E., Pisera, A. B., Manconi, R., Schoenberg, C., Janussen, D., Tabachnick, K. R., Klautau, M., Picton, B., Kelly, M., Vacelet, J., Dohrmann, M., Cristina Díaz, M., and Cárdenas, P.: World Porifera database, available at: www.marinespecies.org/porifera (last access: 16 September 2014), 2014.

Wetzel, F., de Souza, G., and Reynolds, B. What controls silicon isotope fractionation during dissolution of diatom opal?, Geochim. Cosmochim. Ac., 131, 128-137, 2014. 
Wille, M., Sutton, J., Ellwood, M. J., Sambridge, M., Maher, W., and Eggins, S., and Kelly, M.: Silicon isotopic fractionation in marine sponges: a new model for understanding silicon isotopic fractionation in sponges, Earth Planet. Sc. Lett., 292, 281-289, doi:10.1016/j.eps1.2010.01.036, 2010. 